\title{
A.l.-sperm of the stallion: evaluation criteria and minimal standards - a survey
}

\author{
Sieme ${ }^{1,2}$, H. , E. Töpfer-Petersen², H. Bader ${ }^{2}$, R. Petzoldt ${ }^{3}$ and H. Merkt² \\ ${ }^{1}$ Celle National Stud, Germany; ${ }^{2}$ Institute for Reproductive Medicine, Vet. School Hannover, Germany; ${ }^{3}$ Institute for Ecology, University Cottbus, Germany
}

\begin{abstract}
Summary
Evaluation of biological semen quality in stallions is based on analysis of sperm-motility, -morphology, -function and seminalplasma constituents. Methods are listed and discussed in relation to semen preservation techniques and stallion fertility. Minimal standards of stallion A.I.sperm regarding the mainly limiting factors - preservation techniques, sperm dose, frequency, timing and method of A.I. - are demonstrated. Sperm dose for liquid stallion semen transfered during the day of collection should not fall short of than $300 \times 10^{6}$ motile spermatozoa; in the case of chilled transported semen - used 24-36 hours after semen collection - the double dose is recommended. In the case of frozen equine semen good laboratory practice should be a sperm dose of a total of $800 \times 10^{6}$ spermatozoa with a postthaw motility of at least $35 \%$.

Keywords: $\quad$ stallion, semen evaluation, artificial insemination

KB-Sperma des Hengstes: Beurteilungskriterien und Mindestanforderungen - eine Übersicht

Die Beurteilung der biologischen Samenqualität von Hengsten beruht im wesentlichen auf Methoden zur Bestimmung der Spermienmotilität, -morphologie und -funktion sowie der Analyse von Seminalplasmakomponenten. Diese Methoden werden aufgeführt unter Berücksichtigung ihrer Relevanz für die Samenaufbereitungstechnik und Zuchttauglichkeitsuntersuchung. Mindestanforderungen an die für den Besamungserfolg wichtigsten biotechnischen Faktoren - Aufbereitungstechnik, Spermiendosis, Besamungszeitpunkt, Besamungsfrequenz, Besamungsmethode - werden vorgestellt. Bei sachgemäßer Aufbereitungstechnik wird bei Einsatz von flüssigkonservierten Hengstsperma, welches am Tag der Gewinnung $(<12 \mathrm{~h})$ übertragen wird eine Richtdosis von $300 \times 10^{6}$ motilen Spermien empfohlen; bei Einsatz nach 24-36h (Versandsperma) ist die Spermiendosis zu verdoppeln. Bei Einsatz von Tiefgefriersperma sollte die Spermiendosis auf $800 \times 10^{6}$ Spermien mit einer Auftaumotilitäł von mindestens 35\% eingestellt werden.
\end{abstract}

Schlüsselwörter: Hengst, Samenbeurteilung, instrumentelle Samenübertragung

\section{Introduction}

Relationship between in vitro sperm evaluation and in vivo fertility requires further research despite diverse methods to evaluate sperm-motility, -morphology, -function and seminalplasma constituents. Those methods serve in equine reproductive medicine either for fertility prognosis of the individual stallion or in the practical A.I. to estimate correlation and suitability of stallion ejaculates for different semen preservation procedures (fresh, transported, frozen semen).

Regarding correlation of different methodes to male fertility significance of published studies is often problematic in regard to limited numbers of stallions, small number of mares and the use of different scores between studies.

To define standards, variation and minimal criteria of stallion semen Klug (1987) in the warmblood Dowsett and Pattie (1987) as well as Pickett et al (1988) in different breeds analysed raw stallion semen parameters for volume (gel-, gel free-, total semen volume), sperm concentration, total number of spermatozoa per ejaculate, percentage of motile spermatozoa, percentage of morphological normal spermatozoa and seminal $\mathrm{pH}$. Paccamonti et al. (1999) define standards for miniature stallions.

\section{Evaluation criteria}

The classical measurement to assess sperm motility is done by visual estimation using a phase-contrast microscope combined with a warming stage at a magnification of 150 to $200 \mathrm{x}$. Abaxial attachment of the mid piece to the sperm head is physiological in stallion spermatozoa and responsible for a circular motion of a specific aliquote in stallion semen samples. Extended semen should preferably be analyzed because raw stal-lion semen tends to agglutination. Visual estimation is cheap, simple and sufficiently accurate if analysis is created by an experienced technician. Standardization is indicated and recommendations are an incubation temperature of $37^{\circ} \mathrm{C}$, sperm concentration between $25-50 \times 10^{6} \mathrm{sp} . / \mathrm{ml}$, depth of analyzing suspension resp. chamber $10-20 \mathrm{~mm}$ and a minimum of 2 suspensions should be analyzed with 4 to 5 fields near the center of the coverslip.

Computerized semen analysis like the CellSoft system (Stroemberg Mika, Montreux) or the Hamilton Thorne Motility Analyzer (Hamilton Thorne Research, Beverly, MA, USA) were developed as objective methods for quantifiying specific characteristics of sperm motility (VSL straight line velocity, VCL curvilinear velocity, VAP average path velocity, LIN linearity, CIR circular motil 
spermatozoa, STR straightness, LHD lateral head displacement). Malmgren (1997) pointed out that validation of setup and standardization of measuring procedures are important factors if motility analysis is carried out using computerized systems. Regardless that computerized systems provide objective and detailed informations Malmgren (1997) requires further research to compare computerized motility analysis against visual estimation regarding correlation to male fertility.

The relationship beween sperm motility and stallion fertility is often overestimated. Dowsett and Pattie (1982) found no correlation, whereas Samper et al. (1991), Andersson and Katila (1992) and Jasko et al. (1992) found positive correlations between sperm motility and fertility.

Sperm morphology is routinely examined using unstained buffered formol citrate fixation (Hancock 1957) or by using smears with different stains. In stallions Spermac ${ }^{\circledR}$ (Oettle 1986) and Eosin-Nigrosin (Dott and Foster 1972) are often used.

Detailed informations about stallion sperm morphology and sources of origin for different stains are reviewed by Malmgren (1997) and Magistrini et al. (1997).

Regardless that different classification models and scoring tables for stallion spermatozoa exist - like "primary" resp. testicular dependend abnormalities or "secondary" resp. testicular independent abnormalities - a minimum of 200 better 400 spermatozoa should be examined per stain.

Bielanski (1975), Jasko et al (1990) and Clément et al. (1991) found a significant inverse relationship between the amount of sperm abnormalities and stallion fertility.

Morphometric analysis of the sperm head by computer assisted microscopy is preferably used in specialized laboratories mostly using Feulgen or Hematoxylin stains (Davis et al. 1993, Ball and Mohammed 1995). Software is available by using either the ASMA- (automated sperm morphology analysis, Hamilton Thorne Research, Beverly, MA, USA) or SAMBA-TM2005-software (Alcatel TITN, Meylan, France).

Recently developed techniques concentrate on structural abnormalities of the sperm nucleus which possibly could explain idiopathic stallion infertility. The sperm chromatin structure assay (SCSA) is based on susceptibility of spermatozoal nuclear DNA to acid denaturation in situ assesed by flow cytometrie and acridineorange stained spermatozoa. Kenney et al. (1995) described first that susceptibility of spermatozoal DNA denaturation is increased in subfertile stallions.

Tests to evaluate sperm function consist of the use of fluorescent probes, the hypoosmotic swelling test (HOS), sperm filtration tests and sperm oocyte binding tests.

Fluorescent stains assessed by microscope or flow cytometrie serve for detection of plasma membrane integrity, acrosomal status, status of capacitation and mitochondrial activity.

Plasma membrane integrity is controlled using different fluorescent probes in stallion semen. Either membrane permeability and or specific reactions in different compartments of spermatozoa cytosol or specific binding to spermatozoal DNA of the specific fluorescent probe allows diagnosis of live or dead spermatozoa. CFDA (Carboxyfluorescein diacetate) permeates the intact cell membrane is deesterified in the cytosol by nonspecific esterases. Free carboxyfluorescein cumulates inside the cell is nonpermeable and fluoresces green. Additionally CFDA is often combined with Propidium iodide (PI) which cannot penetrate living cells but binds specifically to cellular DNA followed by red fluorescence. Harkema and Boyle (1992) introduced the combination of CFDA/PI, Casey et al. (1993) Hoechst 33258 and Garner and Johnson (1995) SYBR14 in stallion semen. Sieme et al. (1996) using the dual stain CFDA/PI and Magistrini (1997) as well as Vidament et al. (1998) using SYBR14/PI found a significant correlation between stallion sperm motility and plasma membrane integrity.

The process of capacitation is mainly influenced by influx of calcium (Leopold 1994) which is measurable with fluorescent probes like fluo3-AM (Magistrini 1997) or chlortetracyclin (Varner et al. 1987).

Lectins like PSA or PNA bind after membrane permeabilisation to the outer acrosomal membrane. Conjugation with FITC makes evaluation of acrosomal status possible (Casey et al. 1993). Using FITC-PSA Meyers et al. (1995) showed differences between fertile and subfertile stallions after progesteron-induced acrosome reaction. Malmgren et al. (1994) introduced indirect immunfluorescent staining techniques with a monoclonal antibody to evaluate acrosomal status of stallion semen. Grondahl et al (1992) studied acrosomal status of fresh and frozen stallion semen by electron microscopy.

Mitochondrial activity of spermatozoa is evaluated by using the specific fluorescent stain Rhodamine 123 often in combination with a viable stain like PI (Casey et al. 1993). ATP content of the sperm cells was measured using bioluminescence in the stallion by Rodriguez and Bustos-Obregon (1996) and Vidament et al. (1997).

An important mechanism for live cells is the ability of cell membranes to regulate selective transport of molecules. The hypoosmotic swelling test (HOS) allows evaluation of ability of sperm cells to swell in hypoosmotic media as a result of water influx. Lagares (1995) and Petzoldt et al. (1996) evaluated the relationship between HOS and liquid and deep freeze preservation of stallion spermatozoa. Vidament et al. (1998) demonstrated that HOS applied immediately after semen collection shows significant correlations to ATP content and motility of frozen thawed stallion spermatozoa.

Ability of sperm to migrate through different filtration media may correlate with viability. Walter (1992) evaluated different methodes to select stallion spermatozoa (swim-up, percoll, glasswool, glasswool/sephadex) and positive correlations between migration rate and motility as well as percentage of morphological normal spermatozoa. Samper et al. (1991) and Hellander (1992) found a better correlation of sperm filtration rate with GWS to fertility than between motility and fertility. The use of sperm selective media in practical equine A.I. was initiated by Sieme et al. (1997).

Fertilizing capacity of stallion spermatozoa has been studied by zona pellucida binding test (Fazeli et al. 1993). Mostly the homologous hemizona assay (HZA) with two halves of the zona pellucida of a mares oocyte is used in specialized laboratories. Either a test or standard suspension of spermatozoa are incubated each with one hemizona and evaluated afterwards. In the stallion Fazeli et al. (1995) found a significant correlation between number of spermatozoa bound to hemizona and first cycle fertility. 
Seminal plasma modulates multiple functions of spermatozoa during the different steps of sperm maturation and fertilization e.g. post testicular maturation of spermatozoa, sperm transport, interaction with female genitale tract, capacitation, interaction of gametes (Töpfer-Petersen et al. 1998). The major protein components of seminal plasma of the equine were examined for their structure and function by Calvete et al. (1994). Claus et al. (1992) examined their estrogen and PGF2a contents. Reineke et al. (1999) report individual differences in the specific composition of seminal plasma and its relation to stallion fertility.

\section{Minimal standards}

Regarding minimal standards of stallion A.I.-spermatozoa individual stallion fertility, preservation techniques, sperm dose, frequency of A.I., timing of A.I. in relation to ovulation and method of A.I. are main factors limiting equine A.I. practice.

To compare stallion A.l.-programs in different countries suitable studies are published for the french system (Magistrini and Vidament 1999) (Vidament et al. 2000), Northern Europe (Katila 1999), Eastern Europe (Nagy 1999) and the German system (Sieme et al. 1999). Klug et al. (1998) published sanitary principles for stallions in $\mathrm{Al}$-programs.

Factors of semen preservation techniques are extenders, dilution ratio, preparation technique (dilution, centrifugation, alternatives), cooling rate, storage conditions and insemination volume.

In practice extenders are mostly based on skim-milk (SKM) or skim-milk-egg yolk (SKME). The $\mathrm{pH}$ level and osmolarity should be compatible to semen $(7,0 ; 300 \mathrm{mOsm} / \mathrm{L})$. Extenders should be free of particles and well balanced with ions. Regarding balance of ions esp. relation of sodium and potassium is important. A lot of membrane protective substances (milk, egg yolk, BSA, PVA, lipo-proteins, phospholipids, antioxidants) and metabolizable substances are recommended in several in-vitro-studies; but relation to fertility is lacking in most studies.

Dilution requires a relation semen to extender of $\oplus 1: 3$ and/or a sperm concentration after dilution of $\oplus 25 \times 10^{6} / \mathrm{ml}$. Volume of the inseminate should not exceed $50 \mathrm{ml}$.

Transported semen should slowly cool from room temperature to $+5^{\circ} \mathrm{C}\left(0,05^{\circ} \mathrm{C} / \mathrm{min}\right.$.) and stored at $+5^{\circ} \mathrm{C}$ on a roller bench under anaerobic conditions until shipment in adequate containers (Hueck 1990, Katila et al 1997).

Centrifugation of liquid stallion semen is only indicated for long time preserved semen especially shipped semen in those stallions where centrifugation elongates life span of spermatozoa. Success of centrifugation depends on duration (10-15 min.) and centrifugation force (350-700 $\mathrm{g}$ g). Retention of minimum 5 to $20 \%$ of seminal plasma in the resuspension is essential (Ahlemeyer 1991).

Storage of liquid semen at $+15^{\circ} \mathrm{C}$ needs aerobic conditions as demonstrated by Magistrini et al. (1992). Storage conditions seem to have important correlations to fertility (Battelier et al 1997). A critical point is if cooling to $+5^{\circ} \mathrm{C}$ is indicated or not. New studies from France demonstrate benificial and detrimental effects of the different compounds of milk (serving as the major membrane protective substance in equine semen extenders). Native phophocaseinate was found to be the superior substance in milk for liquid storage of equine semen. These authors found significant better fertility with semen extended in modified Hanks solution with Native Phosphocaseinate (INRA96), stored at $+15^{\circ}$ under aerobic conditions in comparison to skim milk based INRA-82 extender stored under anaerobic conditions at $+5^{\circ} \mathrm{C}$ (Battelier et al 1997). Further studies should examine the effect of refrigerator storage in comparison to room temperature storage for longer periods.

Recommended methods to process stallion liquid semen are summarized in Table 1.

Tab. 1: Methods to process stallion liquid semen Methoden der Flüssigsamenaufbereitung bei Hengsten

\begin{tabular}{|c|c|c|c|}
\hline & short term & mid term & long term \\
\hline $\begin{array}{l}\text { preparation } \\
\text { technique }\end{array}$ & raw & dilution & $\begin{array}{c}\text { dilution, } \\
\text { centrifugation } \\
\text { (10min., max } \\
700 \mathrm{~g}), \\
\text { alternatives }\end{array}$ \\
\hline $\begin{array}{l}\text { ratio: } \\
\text { semen: extender }\end{array}$ & & $\begin{array}{c}\oplus 1: 3 \\
\oplus 25 \times 10^{6} \\
\text { sp. } / \mathrm{ml}\end{array}$ & $\begin{array}{c}\oplus 1: 3 \\
\oplus 25 \times 10^{6} \\
\text { sp. } / \mathrm{ml}\end{array}$ \\
\hline cooling rate & & & $0,05 \infty \mathrm{C}$ \\
\hline storage temp. & $\begin{array}{l}+37 \infty \mathrm{C} \\
\text { (>room } \\
\text { temp.) }\end{array}$ & $+15 \infty \mathrm{C}$ & $+5 \infty \mathrm{C}(+15 \infty \mathrm{C} ?$ \\
\hline $\begin{array}{l}\text { storage } \\
\text { conditions }\end{array}$ & - & aerobe & anaerobe \\
\hline extender & - & $\begin{array}{c}\mathrm{pH} \sim 7,0 ; \\
300 \text { mosm., } \\
\text { ionic balanced, } \\
\text { free of particles, } \\
\text { antibiotics }\end{array}$ & $\begin{array}{c}\mathrm{pH} \sim 7,0 ; \\
300 \text { mosm., } \\
\text { ionic balanced, } \\
\text { free of particles, } \\
\text { antibiotics }\end{array}$ \\
\hline $\begin{array}{l}\text { time span: } \\
\text { collection } \tilde{n}> \\
\text { A.l. }\end{array}$ & immediately & $0 \tilde{1} 12 \mathrm{~h}$ & $24 \tilde{n} 36 \mathrm{~h}$ \\
\hline practicability & $(\tilde{n})$ & + & + \\
\hline
\end{tabular}

The basic of cryopreservation success is the individual stallion itself. Frozen semen of stallions is preferably prepared during the non-breeding season. Sexual rest, individual sperm production capacity and hygienic conditions are important factors preceeding freezing campagne. A depletion of extragonadal sperm reserves until good sperm quality is established is recommended after long sexual rest. Preferable semen collection interval to prepare frozen semen is 48 hours. Above recommendations should be adapted to the individual stallion. Comparing protocols of different countries methods for freezing stallion semen and instructions for insemination mares with frozenthawed semen are far from standardized (Samper and Morris 1998). Published procedures are selected and summarized in Table 2 . 
Tab. 2: Methods to process stallion frozen semen

Methoden der Tiefgefriersamenaufbereitung bei Hengsten

\begin{tabular}{|c|c|c|}
\hline Source & Packaging & Thawing \\
\hline $\begin{array}{l}\text { Merkt and Krause } \\
\text { (1966) }\end{array}$ & Pellets & $\begin{array}{l}\text { warmed thawing } \\
\text { solution }\end{array}$ \\
\hline Tischner (1979) & $\begin{array}{l}\text { Aluminium } \\
\text { tubes } \\
(20-25 \mathrm{ml})\end{array}$ & $40^{\circ} \mathrm{C} . / 50 \mathrm{sec}$. \\
\hline $\mathrm{He}$ (1986) & $\begin{array}{l}\text { Glass-vials } \\
(1 \mathrm{ml})\end{array}$ & $\begin{array}{l}\text { in } 20 \mathrm{ml} \text { sucrose-milk } \\
\text { solution }\end{array}$ \\
\hline Martin et al. (1979) & $\begin{array}{l}\text { Macrotüb } \AA \\
(4,0 \mathrm{ml} \text { straw })\end{array}$ & $50^{\circ} \mathrm{C} / 40 \mathrm{sec}$. \\
\hline Loomis et al. (1983) & $0,5 \mathrm{ml}$ straw & $38^{\circ} \mathrm{C} / 30 \mathrm{sec}$ \\
\hline Cochran et al. (1984) & & $\begin{array}{l}37^{\circ} \mathrm{C} / 30 \mathrm{sec} . \text { or } \\
75^{\circ} \mathrm{C} / 7 \mathrm{sec} .\end{array}$ \\
\hline $\begin{array}{l}\text { Palmer (1984) } \\
\text { mod.Vidament et } \\
\text { al.(2000) }\end{array}$ & & $37^{\circ} \mathrm{C} / 30 \mathrm{sec}$ \\
\hline $\begin{array}{l}\text { Håård and Håård } \\
\text { (1991) }\end{array}$ & & $\begin{array}{l}75^{\circ} \mathrm{C} / 7 \mathrm{sec} . \\
\text { followed by } 35^{\circ} \mathrm{C} \\
10-30 \mathrm{sec} .\end{array}$ \\
\hline $\begin{array}{l}\text { Wöckener et al. } \\
\text { (1992) }\end{array}$ & & $37^{\circ} \mathrm{C} / 30 \mathrm{sec}$. \\
\hline
\end{tabular}

Despite major role of fertility of the individual stallion and role of preservation techniques it's obvious that sperm dose (see Table 3), frequency of preovulatory inseminations, timing of A.I. in relation to ovulation as well as method of A.I. are important limiting factors. Nevertheless published data concerning interrelationship between these factors are often contradictory (Gahne et al. 1998, Shore et al. 1998, Squires et al. 1998). Regarding liquid preserved semen two inseminations containing each $1 \times 10^{9}$ progressively motile spermatozoa given on two consecutive days before ovulation are recommended by Squires et al. (1998). Magistrini and Vidament (1999) prefer two preovulatory inseminations with $200 \times 10^{6}$ spermatozoa from stallions of normal fertility inseminated in a 48 hours interval in the case of semen stored not longer than 12 hours; semen stored longer than 12 hours should been inseminated daily until ovulation. $400 \times 10^{6}$ fresh spermatozoa is their recommended dose for subfertile stallions. Gahne et al. (1998) found no difference in fertility using either 300 or $500 \times 10^{6}$ fresh spermatozoa. Calculation of sperm doses in the Netherlands is based on percentage of total morphological normal and motile spermatozoa (TNM) with 300 TNM for fresh semen and 600 TNM for transported liquid semen (Parlevliet 1997). In the German routine A.I. practice a dose of $500 \times 10^{6}$ motile spermatozoa is used (Büttelmann 1988, Sieme et al. 1999). To conclude sperm dose for liquid stallion semen transfered during the day of collection should not be less than $300 \times 10^{6}$ live spermatozoa; in the case of chilled transported semen - used 24-36 hours after semen collection the double dose is recommended.

In routine practice manual semen transfer into the uterine body is generally used. If semen is deposited in the uterine horn ipsilateral to the ovulatory follicle fertility results are improved (Feo et al. 1992). A new approach is the hysteroscopic insemination of low numbers of sperms at the uterotubal junction (Morris et al. 2000)

In the case of frozen semen Pace and Sullivan (1975) observed significant better fertility results inseminating within 12 hours of ovulation, by decreasing glycerol level in freezing extender from $7 \%$ to $2 \%$, by increasing the number of motile spermatozoa from $40 \times 10^{6}$ to $80 \times 10^{6}$ but not further with $160 \times 10^{6}$ or by increasing the frequency of inseminations from once to twice daily. Magistrini and Vidament (1999) found best fertility results using $400 \times 10^{6}$ spermatozoa with a postthaw motility of min. $35 \%$ inseminating twice on two consecutive days in the preovulatory period; three inseminations led to significant better fertility than 2 inseminations (Vidament et al. 1997). Using this technique Vidament et al. (2000) observed a per cycle pregnancy rate of $49 \%$ ( $n=4190$ cycles). Leipold et al. (1998) recommend a total dose of $800 \times 10^{6}$ spermatozoa respectively $320 \times 10^{6}$ motile spermatozoa. Samper (1995) observed better fertility with frozen stallion semen with increasing sperm doses until $800 \times 10^{6}$ spermatozoa. According to Samper and Morris (1998) frozen stallion semen should be used once and as close to ovulation as possible. Induction of ovulation by hormonal intervention could be a helpful tool in handling frozen stallion semen (Sieme and Klug 1996). Regarding fertility a comparative study between the multiple preovulatory insemination regimen (French system) and the single A.I. system preferably in the preovulatory period (12-6 hours before ovulation) is missing.

Tab. 3: Recommended sperm doses for stallion semen in different countries Inseminationsdosen für Hengstsperma in verschiedenen Ländern

\begin{tabular}{|c|c|c|c|c|}
\hline Sperm dose $\left(\times \mathbf{1 0}^{6}\right)$ & Fresh semen $(<\mathbf{1 2 h})$ & Chilled transport. (24ñ6h) & Frozen semen & Frozen semen quality \\
\hline France (INRA) & 200 & 400 & 400 & $35 \%$ motile \\
\hline TheNetherlands (Utrecht) & 300 TNM & 600 TNM & 300 TNM & TNM \\
\hline Germany (Hannover) & 300 progr. mot. & 600 progr. mot. & 800 & $35 \%$ motile \\
\hline North. Europe (Upsalla) & 500 & 1.000 & & \\
\hline USA & 500 progr. mot. (1×109) & & 800 & $>300$ motile \\
\hline
\end{tabular}


As long as frozen equine semen is sold on the basis of single insemination doses good laboratory practice should be a sperm dose of a total of $800 \times 10^{6}$ spermatozoa with a postthaw motility of at least $35 \%$.

\section{Literature}

Ahlemeyer, B. (1991): Tiefgefrierkonservierung von Hengstsamen, Einfluß des Seminalplasmas auf Motilität und Kopfkappenintegrität der Samenzellen. Hannover, Tierärztl. Hochsch. Diss.

Andersson, M. and T. Katila (1992): Evaluation of frozen thawed stallion semen with a motility analyzer. $12^{\text {th }}$ Int. Congr. Anim. Reprod., The Hague, 1837-1839.

Ball, B.A. and H.O. Mohammed (1995): Morphometry of stallion spermatozoa by computer assisted-image analysis. Theriogenology, 44, 367-377

Battelier, F., M. Magistrini, J. Fauquant and E. Palmer (1997): Milk fractions are effective for stallion semen preservation. Theriogenology, 48(3), 391-410

Bielanski W. (1975): The evaluation of stallion semen in aspects of fertility control and its use for artificial insemination. J. reprod. Fert., 23, 19-24

Büttelmann, A. (1988). Auswertung der Daten einer Pferdebesamungsstation. Hannover, Tierärztl. Hochsch. Diss.

Calvete, J.J., S. Nessau, K. Mann, L. Sanz, H. Sieme, E. Klug and E. Töpfer-Petersen (1994): Isolation and characterization of stallion seminal-plasma proteins. Reprod. Dom. Anim. 29, 411-426

Casey, P.J., R.B. Hillmann, K.R. Robertson, A.Y. Yudin, I.K. Liu and E.Z. Drobnis (1993): Validation of an acrosomal stain for equine sperm that differentiates between living and dead sperm. J. Androl., 14, 289-297

Claus, R., M.A. Dimmick, T. Giminez and L.W. Hudson (1992): Estrogens and Prostaglandin F2a in the semen and blood of stallions. Theriogenology 38, (4), 687-693

Clément, F, M. Hochereau, C. Perreau and M. Magistrini (1991): Alterations of the semen and genital tract of infertile stallions. J. Reprod. Fert. 44, Suppl., 657-659

Davis, R.O., C.G. Gravance, and P.J. Casey (1993): Automated morphometric analysis of stallion spermatozoa. Am. J. Vet. Res., 54, 1801-1811

Cochran, J.D., R.P. Amann, E.L. Squires and B.W. Pickett (1984): Effects of centrifugation, glycerol level, cooling to $5^{\circ} \mathrm{C}$, freezing rate and thawing rate on the post-thaw motility of equine sperm. Theriogenology 22, 1, 25-38

Dott, H.M. and G. Foster (1972): A technique for studying the morphology of mammalian spermatozoa which are eosinophilic in a differential live/dead stain. J. Reprod. Fertil. 29, 443-445

Dowsett, K.F. and W.A. Pattie (1982): Characteristics and fertility of stallion semen. J. Reprod. Fert. 32 Suppl., 1-8

Dowsett, K.F. and W.A. Pattie (1987): Variation in characteristics of stallion semen caused breed, age and season of year and service frequency. J. Reprod. Fert., 35, 645-648

Fazeli, A.R., W. Steenweg, M.M. Bevers, V. Bracher, J. Parlevliet and B. Colenbrander (1993): Use of sperm binding to homologous hemizona pellucida to predict stallion fertility. Equine Vet. J. 15 Suppl., 57-59

Fazeli, A.R., W. Steenweg, M.M. Bevers, J. van den Broeck, V. Bracher, J. Parlevliet and B. Colenbrander (1995): Relation between stallion sperm binding to homologous hemizonae and fertility. Theriogenology 44, 751-760

Feo, J.C., E. Oba, R.C. Barnabe and J.R. Basile (1992): Artificial insemination in the Equiune: Distribution of spermatozoa in the genital tract; a comparison of mares inseminated in the uterine body and the uterine horn ipsilateral to the ovulatory follicle. $12^{\text {th }}$ Int. Congr. Anim. Reprod., The Hague, Aug.- 23 ${ }^{\text {rd }} 27^{\text {th }}$, pp 1545-1547
Gahne, S., A. Ganheim and L. Malmgren (1998): Effect of insemination dose on pregnancy rate in mares. Theriogenology 49, 1071-1074

Garner, D.L. and L.A. Johnson (1995): Viability assessment of mammalian sperm using SYBR 14 and propidium iodide. Biolog. Reprod., 53, 276-284

Gather, C. (1994). Einfluß eines mittels Tyrode-Medium modifizierten Magermilchverdünners auf Motilität, Morphologie und Vitalität flüssigkonservierten Hengstspermas. Hannover, Tierärztl. Hochsch., Thesis

Grondahl, C., P. Hyttel and P. Greve (1992): Acrosome status of fresh and frozen/thawed stallion spermatozoa evaluated by scanning electron microscopy. In: Proc. $12^{\text {th }}$ Int. Congr. Anim. Reprod.. The Hague, 1870-1871

Håård, M.C. and M.G.H. Håård (1991): Successful commercial use of frozen stallion semen abroad. J. Reprod. Fert., Suppl. 44, 647-648

He, (1986): cit. in Amann, R.P. and B.W. Pickett (1987): Principles of cryopreservation and a review of cryopreservation of stallion spermatozoa. Equine Vet. Sci. 7, 3, 145-173

Harkema, W. and M. Boyle (1992): Use of fluorescent stains to assess membrane integrity of equine spermatozoa. In: Proc. $12^{\text {th }}$ Int. Congr. Anim. Reprod.. The Hague, 1424-1426

Hellander, J. (1992): Current practical use of glasswool/sephadex filtration technique of frozen stallion semen. Acta vet Scand. Suppl. $88,67-70$

Hueck, C. (1990): Untersuchungen zur Flüssigkonservierung von Pferdesperma unter Verwendung verschiedener Kühl- und Transportsysteme - Laborstudie. Hannover, Tierärztl. Hochsch. Diss.

Jasko, D.J., T.V. Litlle, D.H. Lein and R.H. Foote (1992): Comparison of spermatozoal movement and semen charcteristics with fertility in stallions: 66 cases (1987-1988). JAVMA, 197, 389-394

Jasko, D.J., D.H. Lein and R.H. Foote (1992): Determination of the relationship between sperm morphological classifications and fertility in stallions: 64 cases (1987-1988). JAVMA, 200, 979-985

Jeyendran, R.S., H.H. Van der Veen, M. Perez-Pelaez, B.G. Crabo and L.J.D Zanefeld (1984). Development of an assay to assess the functional integrity of the human sperm membrane and its relationship to other semen characteristics. J.Reprod.Fert. 70, 219-228

Katila, T. (1997): Procedures for handling fresh stallion semen. Theriogenology 48, 1217-1227

Katila, T. (1999): Dévelopment et conséquences des nouvelles techniques de reproduction chez les juments en Europe du nord. 25ème journée de la recherche équine. Edition Institut du Cheval, 77-81

Kenney, R.M., D.P. Evenson, M.C. Garcia and C.C. Love (1995): Relationship between sperm chromatin structure, motility and morphology of ejaculated sperm and seasonal pregnancy rate. Biol. Reprod. Mono., 1, 647-653

Klug, E. (1982): Untersuchungen zur klinischen Andrologie des Pferdes. Die Bedeutung andrologischer Befunde am Hengst für den Zuchteinsatz. Hannover, Tieräörzłl. Hochsch., Habil.-Schr.

Klug, E., H. Sieme und E. Peters (1998): Hygiengrundlagen zum Einsatz von Hengsten in der instrumentellen Samenübertragung. Tierärztl. Prax., 26, 218-24

Lagares (1995): Determination of osmotic resistance of stallion spermatozoa. Hannover, Tieräztl. Hochsch., Thesis

Leipold, S.D., J.K. Graham, E.L. Squires, P.M. Mc Cue, S.P. Brinsko and D.K. Vanderwall (1998): Effect of spermatozoal concentration and number on fertility of frozen equine semen. Theriogenology 49, 15371543

Leopold, S. (1994): Factors affecting $\mathrm{Ca}^{2+}$ flux in equine spermatozoa. Hannover, Tieräzłl. Hochsch., Thesis

Loomis, P.R., R.P. Amann, E.L. Squires and B.W. Pickett (1983): Fertility of unfrozen and frozen stallion spermatozoa extended in EDTA-lactose-egg yolk and packaged in straws. J. Anim. Sci. 56, 687-693

Malmgren, L., B. Op den Kamp, A. Wöckener, M. Boyle and B. Colenbrander (1994): Motility, velocity and acrosome integrity of equine spermatozoa stored under different conditions. Reprod. Dom. Anim. 29, 469-476

Malmgren, L. (1997): Assessing the quality of raw semen: A review. Theriogenology 48, 523-530 
Magistrini, M., E. Guitton, Y. Levern, J.Cl. Nicolle, M. Vidament, D. Kerboeuf and E. Palmer (1997): New staining methods for sperm evaluation estimated by microscopy and flow cytometrie. Theriogenology, 48, 1229-1235

Magistrini, M. and M. Vidament (1999): L'insémination artificielle équine: des technologies à géométrie variable. 25ème journée de la recherche équine. Edition Institut du Cheval, 117-128

Martin, J.C. E. Klug and A.R. Günzel-Apel (1979): Centrifugation of stallion semen and its storage in large volume straws. J. Reprod. Fert. Suppl. 27, 47-51

Merkt, $H$. und D. Krause (1966): Tiefgefrierspermaversuche mit Equidensperma unter Anwendung des sog. Pellet-Verfahrens. Dtsch. Tierärztl. Wochenschr. 78, 127-129

Meyers, S.A., S.W. Overstreet, I.K. Liu and E. Drobnis (1995): Capacitation in vitro of stallion spermatozoa; comparison of progesteroneinduced acrosome reactions in fertile and subfertile males. J. Androl. $16,47-54$

Morris, L.H.A., R.H.F. Hunter and W.R. Allen (2000): Hysteroscopic insemination of small numbers of spermatozoa at the uterotubal junction of preovulatory mares. J. Reprod. Fert. 1 18, 95-100

Nagy, P. (1999): Dévelopment des techniques de reproduction chez le cheval en Hongrie: un exemple de l'Europe de l'Est. 25ème journée de la recherche équine. Edition Institut du Cheval, 83-87

Pace M.M. and J.J. Sullivan (1975): Effect of timing of insemination, numbers of spermatozoa and extender components on the pregnancy rate in mares inseminated with frozen stallion semen. J. Reprod. Fert. Suppl. 23, 115-121

Paccamonti; D.L., A.V. Buiten, J.M. Parlevliet and B. Colenbrander (1999): Reproductive parameters of miniature stallions. Theriogenology 51, 1343-1349

Palmer, E. (1984): Factors affecting stallion semen survival and fertility. In: Proc. 10 th Int. Congr. Anim. Reprod. \& Al. Urbana 1984, pp. 377

Parlevliet, J. (1997): Clinical aspects of stallion fertility. Proefschrift, University Utrecht

Petzoldt, R., H. Sieme, C. Kohne, E. Töpfer-Petersen and E. Klug (1996): Relationship between stallion sperm swelling in hypoosmotic medium (HOS) and liquid and deep freeze preservation. Symposium on Stallion Semen, Amersfoort-The Netherlands, March 7-8 (personal communication).

Pickett, B.W., J.L.Voss, R.A. Bowen, E.L. Squires and A.O. McKinnpn (1988): Seminal characteristics and total scrotal width (T.S.W.) of normal and abnormal stallions. Proc. Am. Assoc. Equine Pract., 485518

Reineke, A., O.Heß, A. Schambony, A.M. Petrounkina, H. Bader, H. Sieme and E. Töpfer-Petersen (1999): Sperm-associated seminal plasma proteins - a novel approach for the evaluation of sperm fertilizíng ability of stallions? Pferdeheilkunde 15, 531-37

Rodriguez, H. and E. Bustos-Obregon (1996): Seasonality and freezability vs routine parameters in stallion semen. Histology and Histopathology 1 1, 426-430

Samper, J.C., J. Hellander and B. Crabo (1991): Relationship between the fertility of fresh and frozen stallion semen and semen quality. J. Reprod. Fert., Suppl., 107-114

Samper, J.C. (1995): Stallion semen cryopreservation: Male factors affecting pregnancy rates. Proc. Soc. For Theriogenology. San Antonio $T X, 160-165$

Samper, J.C. and C.A. Morris (1998): Current methods for stallion semen cryopreservation: a survey. Theriogenology, 895-903
Shore, M.D., M.L. Macpherson, G,B. Combes, D.D. Varner and T.L. Blanchard (1998): Fertility comparison between breeding at 24 hours or at 24 and 48 hours after collection with cooled equine semen. Theriogenology 50, 693-698

Sieme, H., S. Kneißl, I. Roebbelen, R. Petzoldt, E. Klug, and E. TöpferPetersen (1996): Cryopreservation of stallion semen - influence of collection methode, packaging form and freezing rate. Symposium on Stallion Semen, Amersfoort-The Netherlands, March 7-8 (personal communication).

Sieme, H. und E. Klug (1996): Spezielle Erfahrungen mit der gezielten Ovulationssteverung bei der Stute zur Samenübertragung. Collegium veterinarium $\mathrm{XXVI}, 76-78$

Sieme, H., E. Klug and H. Bader (1997): Separation techniques to achieve subpopulations of vital and fertile equine spermatozoa - $A$ survey. Dtsch. Tierärztl. Wschr. 104, 298-302

Sieme, H., E. Klug and H. Merkt (1999): Organistaion de l'insémination artificielle en Allemagne. 25ème journée de la recherche équine. Edition Institut du Cheval, 129-137

Squires, E.L., J.K. Brubaker, P.M. McCue and B.W. Pickett (1998): Effect of sperm number and frequency of insemination on fertility of mares inseminated with cooled semen. Theriogenology 49, 743-749

Tischner, M. (1979): Evaluation of deep-frozen semen in stallions. J. Reprod. Fert. Suppl. 27, 53-59

Töpfer-Petersen, E., D. Waberski, O. Hess, S. Bellair, A. Schambony, M. Ekhlasi-Hundrieser, M. Gentzel, A. Reineke und J. Calvete (1998): Bedeutung des Seminalplasmas für die Befruchtung - ein Überblick. Tierärztl. Umschau 53

Varner, D.D., C.R. Ward, B.T. Storey and R.M. Kenney (1987): Induction and characterisation of acrosome reaction in equine sperm. Am J. Vet. Res. 48, 1383-1389

Vidament, M., A.M. Dupere, P. Julienne, A. Evain, P. Nove and E. Palmer (1997): Equine frozen semen freezability and fertility field results. Theriogenology 48, 907-17

Vidament, M., E. Cognard, J.M. Yvon, M. Sattler, E. Palmer and M. Magistrini (1998): Evaluation of stallion semen before and after freezing. Reprod. Dom. Anim. 33, 269-277

Vidament, M., M. Magistrini, E. Palmer and F. Clément (2000): Equine Artificial Insemination in French National Studs. Reprod. Dom. Anim. Suppl. 6, 61-66

Walter K. (1992): Influence of different spermatozoa selection methodes and motility, viability and morphology of equine sperm cells and their diagnostic significance. Hannover, Tieräztl. Hochsch., Thesis

Wöckener, A. L. Malmgren, B. Op Den Kamp, M. Boyle, H. Badere and B. Colenbrander (1992): Freezing of stallion semen - effects on sperm motility and morphology. $12^{\text {th }}$ Int. Congr. Anim. Reprod., The Hague, Aug.- $23^{\text {rd }} 27^{\text {th }}$, pp $1933-1935$

\section{Dr. Harald Sieme}

Niedersächsisches Landgestüt Celle

Spörckenstr. 10

29221 Celle, Germany

Tel./Fax: 05141/9294 0/31

Email: landgestuet.celle@t-online.de 